\title{
Pengaruh Pemberian Ekstrak Biji Mahoni (Swietenia mahagoni) terhadap Kematian Larva Culex sp
}

\author{
Effects of Mahoni Seeds Extract (Swietenia mahagoni) on Culex sp. Larvae Mortality
}

\author{
Lisa Hidayati ${ }^{*}$, Seli Suprihatini ${ }^{2}$ \\ 1Promosi Kesehatan, Institut Kesehatan Prima Nusantara Bukittinggi, Jl. Kusuma Bhakti No. 99 Gulai \\ Bancah, Kota Bukittinggi, Sumatera Barat, Kode Pos 26122, Indonesia \\ ${ }^{2}$ Analis Kesehatan, Politeknik Piksi Ganesha, Jln. Gatot Subroto no. 301, Kota Bandung, Kode Pos 40274, \\ Indonesia
}

\begin{abstract}
Mahogany seed extract (Swietenia mahagoni) is a natural larvacidal material that contains limonoid, flavonoid, saponins, and alkaloid. Mahogany seed extract can kill Culex sp larvae, known as filariasis vectors. Control with conventional larvicides carries a risk of resistance so alternatives are needed. The study observed the effect of mahogany seed extract on Culex sp. larvae mortality. This study utilized an experimental method with ANOVA and probit analysis to determined $L C_{50}$ and $L T_{50}$. The extraction method was used in this study was the maceration method. This research used some variation of mahogany seed extract concentration, consist of 8\%, 10\%, 20\%, 50\%, with negative control (-) used distilled water. Research repetition was carried out 3 times with a total sample of 325 larvae. Observations were made at 15, 60, 120, 240, 420, and 720 minutes (12 hours). The result of the study showed that there was a significant effect between the concentration of mahogany seed extract on larval mortality. The concentration that effectively kills $50 \%$ of Culex sp. $\left(L C_{50}\right)$ larvae was 10\%. The time which was needed to kill 50\% of Culex sp (LT50) larvae was 204,23 minutes. The higher the concentration level of mahogany seed extract was used the more larval mortality rates. The morphology after administration of mahogany seed extract was damaging in the caput, thorax, and abdomen due to the mechanism of action of mahogany seed extract as an antifeedant and larvae body structure is more transparent. This research can be using mahogany seed extract with different methods and larvae. Mahogany seed extracts are expected to be applied in society as vector control and this research can be developed using mahogany seed extract with different methods and larvae.
\end{abstract}

Keywords: Mahogany seeds, Extract, Culex sp, Larvacidal, Maceration, LC50, LT50

\begin{abstract}
Abstrak. Ekstrak biji mahoni (Swietenia mahagoni) merupakan bahan larvasida alami yang mengandung limonoid, flavonoid, saponin, dan alkaloid. Ekstrak biji mahoni diduga bisa membunuh larva Culex sp. yang berperan sebagai vektor filariasis. Pengendalian dengan larvasida konvensional memiliki risiko resistensi sehingga perlu dicarikan alternatif bahan lain. Tujuan dari penelitian ini untuk melihat pengaruh ekstrak biji mahoni terhadap kematian larva Culex sp. Penelitian ini menggunakan metode eksperimental dengan analisis ANOVA dan analisis probit untuk menentukan $\mathrm{LC}_{50}$ dan $\mathrm{LT}_{50}$. Metode ekstraksi yang digunakan dalam penelitian ini adalah modifikasi maserasi. Konsentrasi ekstrak biji mahoni yang diujikan yaitu 8\%, 10\%, 20\%, 50\%, dengan kontrol (-) menggunakan aquades. Pengulangan dilakukan sebanyak 3 kali dengan total sampel 325 larva. Pengamatan dilakukan pada menit ke 15, 60, 120, 240, 420 dan 720 menit (12 jam). hasil penelitian ini memperlihatkan adanya pengaruh yang signifikan antara konsentrasi ekstrak biji mahoni terhadap kematian larva. Konsentrasi yang efektif membunuh 50\% larva Culex sp (LC50) adalah 10\%. waktu yang dibutuhkan untuk membunuh 50\% larva Culex sp. (LT50) adalah 204,230 menit. Semakin tinggi tingkat konsentrasi ekstrak biji mahoni semakin tinggi pula tingkat kematian larva. Morfologi larva setelah pemberian ekstrak biji mahoni mengalami kerusakan di bagian caput, toraks dan abdomen karena mekanisme kerja ekstrak biji mahoni sebagai antifeedant dan struktur tubuh larva lebih transparan. Ekstrak biji mahoni diharapkan dapat diaplikasikan di dalam masyarakat sebagai pengendalian vektor. Penelitian ini bisa dikembangkan menggunakan ekstrak biji mahoni dengan metode dan larva yang berbeda.
\end{abstract}

Kata Kunci: Biji mahoni, Ekstrak, Culex sp, Larvasida, Maserasi, LC50, LT50

Naskah masuk: 22 Agustus 2019| Revisi: 20 Mei 2020 | Layak terbit: 20 Juni 2020

${ }^{*}$ Corresponding Author. E-mail: lisahidayatidnr@gmail.com | Tlp : +62 81363690817 


\section{PENDAHULUAN}

Filariasis merupakan penyakit parasit yang umumnya disebut penyakit infeksi tropis yang disebabkan oleh cacing nematoda yang berasal dari superfamili Filarioidea atau dikenal juga dengan Filariae. Cacing parasit ini disebarkan oleh arthropoda pengisap darah, umumnya lalat hitam dan nyamuk. ${ }^{1}$

Nyamuk merupakan serangga pembawa penyakit, karena keberadaannya berfungsi sebagai vektor pembawa bibit penyakit $\mathrm{Di}$ Indonesia, Genus Culex berperan sebagai vektor utama penularan filariasis. Selain Culex, filariasis juga dapat ditularkan oleh beberapa vektor dari genus lain. Saat ini telah dikonfirmasi nyamuk dari genus Mansonia dan Anopheles yang juga berperan sebagai vektor filariasis di Indonesia ${ }^{2}$. Culex sp. memiliki populasi yang lebih banyak dilingkungan dari pada jenis nyamuk lainnya. Culex sp. dapat menjadi vektor penyakit filariasis dan demam Japanese encephalitis. ${ }^{3}$

Provinsi Jawa Barat pada tahun 2017 menempati urutan ke-4 kasus kronis filariasis terbanyak di Indonesia sebanyak 907 kasus di 11 kabupaten/kota tersebar di Jawa Barat setelah Papua, Nusa Tenggara Timur, dan Papua Barat. Kabupaten Sumedang merupakan wilayah yang berbatasan langsung dengan kabupaten garut, Kabupaten Majalengka, Kabupaten Subang, dan Kabupaten Bandung yang memiliki curah hujan cukup tinggi $323 \mathrm{~mm}^{3}$ dilihat dari posisi Kabupaten Sumedang yang berbatasan dengan wilayah kasus filariasis dan curah hujan yang cukup tinggi sebagai tempat perindukan nyamuk karenanya wilayah ini berpotensi sebagai wilayah kasus filariasis. ${ }^{4}$

Salah satu pengendalian larva yang sudah diterapkan dalam masyarakat adalah penggunaan insektisida kimia yaitu larvasida sintetik. Walaupun larvasida sintetik telah lama digunakan mulai dari tahun 1976, tetapi penggunaan insektisida dalam jenis apapun membawa dampak negatif terhadap manusia karena bahan yang digunakan mengandung senyawa sintetik dan berbahaya jika melebihi dosis penggunaan. ${ }^{3}$ Selain itu, penggunaan insektisida sintetik seperti malathion, bendiokarb, dan deltamethrin telah dilaporkan menimbulkan resistensi terhadap nyamuk. ${ }^{3}$

Larvasida sintetik merupakan produk yang paling umum digunakan masyarakat saat ini untuk memutus rantai penularan penyakit yang ditularkan oleh nyamuk terutama Culex dan Aedes. Larvasida umunya menggunakan bahan aktif, seperti DDT (Dichloro Diphenyil Trichloroethane), etilheksanol, temefos, dan berbagai senyawa sintetik lainnya. Penggunaan insektisida sintesis khususnya larvasida menimbulkan beberapa efek samping, diantaranya adalah resistensi terhadap serangga, pencemaran lingkungan, dan residu insektisida. ${ }^{5}$

Guna menghindari gangguan atau gigitan nyamuk Culex sp. selain dengan cara pemberantasan vektor juga dapat menggunakan repelan. Namun, sebagian besar komposisi dari repelan mengandung $N, N$-diethyl-m-toluamide (DEET) yang mekanisme aksinya dengan cara menghambat aktifitas sistem saraf pusat dan enzim acetylcholinesterase serangga maupun mamalia. Senyawa DEET merupakan contoh bahan penolak nyamuk dari bahan kimia yang tidak berbau, tetapi mempunyai efek samping yang dapat mengiritasi mata dan menimbulkan rasa terbakar pada kulit yang terluka atau jaringan membran. ${ }^{6}$

Pencarian bahan yang bersumber dari alam untuk pengembangan larvasida alami sangat diperlukan. Larvasida alami diharapkan mampu mengendalikan populasi nyamuk penular penyakit. Beberapa tanaman di alam memiliki manfaat sebagai insektisida dan relatif tidak berbahaya serta dapat diterima masyarakat ${ }^{7}$. Larvasida alami dapat dikembangkan dari tumbuhan yang mengandung senyawa kimia aktif yang terdapat pada berbagai bagian tanaman, seperti akar, daun, biji, kulit batang dan buah. Beberapa insektisida alami mengunakan berbagai tanaman yang mengandung zat toksik bagi larva nyamuk. ${ }^{8}$

Salah satu tanaman yang mengandung insektisida nabati dan berpotensi sebagai larvasida adalah mahoni (Swietenia mahagoni). Biji mahoni mengandung insektisida berupa senyawa alkaloid, flavonoid, dan saponin ${ }^{9}$ serta limonoid. ${ }^{10}$

Chaieb menyatakan bahwa tumbuhan mahoni mengandung senyawa kimia yang dapat menghambat kemampuan makan larva (antifeedant) akibat kandungan senyawa saponin dan flavonoid dalam biji mahoni. Senyawa saponin dan flavonoid diketahui berperan sebagai racun perut terhadap larva sehingga alat pencernaannya akan terganggu. Selain itu, senyawa tersebut juga menghambat reseptor perasa pada mulut larva yang menyebabkan larva gagal mendapatkan stimulus rasa sehingga tidak mampu mengenali makanan. ${ }^{11}$ Penelitian yang dilakukan Rasyad, menggunakan ekstrak biji mahoni pada tikus putih galur wistar menunjukan efek lain dari saponin dan flavonoid yang dapat menghambat kerja hormon pada hewan, yaitu hormon otak, hormon ekdison, dan hormon pertumbuhan. Fungsi lain dari senyawa tersebut yaitu menghambat fungsi saraf (enzim kolinesterase) sehingga akan terjadi gangguan 
transmisi rangsang yang menyebabkan menurunnya koordinasi otot dan kematian pada larva. ${ }^{12}$ Dilihat dari beberapa penelitian sebelumnya masih sedikit yang menggunakan ekstrak biji mahoni sebagai larvasida alami. Penggunaan ekstrak daun mahoni telah terbukti membunuh Culex vishnui ${ }^{13}$ dan juga Anopheles stephensi ${ }^{14}$ baik dalam bentuk jelly, coil maupun serbuk nanopartikel. ${ }^{15}$ Akan tetapi, belum ada yang menggunakan biji mahoni sebagai pengendalian larva Culex.

Berdasarkan uraian di atas maka peneliti tertarik untuk melakukan penelitian tentang pengaruh ekstrak biji mahoni (Swietenia mahagoni) terhadap kematian larva Culex sp. dengan melihat morfologi larva sebelum dan sesudah pemberian ekstrak, konsentrasi, dan waktu yang efektif. Penelitian ini diharapkan dapat menghasilkan alternatif larvasida alami untuk memutuskan siklus hidup nyamuk Culex sp. sehingga populasinya dapat dikurangi.

\section{BAHAN DAN METODE}

\section{Lokasi dan Waktu Penelitian}

Lokasi pengambilan sampel larva Culex sp. dilakukan di beberapa rumah di Dusun Bantargintung Desa Karyamukti Kecamatan Tomo Kabupaten Sumedang Sampel biji mahoni juga didapatkan ditempat yang sama. Setelah itu uji dilakukan di laboratorium Parasitologi dan Mikrobiologi Analis Kesehatan Politeknik Piksi Ganesha Bandung. Penelitian ini dilakukan pada Januari - Juni 2019.

\section{Populasi dan Sampel Penelitian}

Penelitian menggunakan larva instar III karena larva instar III relatif stabil dari pengaruh faktor eksternal, dan larva instar III sudah memiliki ketahanan hidup yang kuat. Laju ketahanan hidup atau survival rate (SR) fase akuatik dari Culex mengalami masa rentan pada fase instar I ke instar II. ${ }^{16}$

Larva di ambil dari beberapa rumah di Dusun Batargitung Desa Karyamukti Kecamatan Tomo Kabupaten Sumedang, menggunakan gayung dan wadah plastik untuk menampung larva.

Pengambilan larva menggunakan gayung bertangkai panjang dan ditampung ke dalam ember kecil. Larva dimasukan ke dalam plastik klip 10x17,6 cm masing-masing 25 larva. Kemudian, larva di bawa ke laboratorium Rumah Sakit Sariningsih Bandung untuk diidentifikasi jenis larva (Gambar 1).

Dari pencarian tersebut di dapatkan 413 larva. Larva diseleksi berdasarkan stadium dan dipilih larva stadium III untuk dilakukan uji. Larva dipilih berdasarkan ukuran yang relatif sama sehingga diperoleh 325 larva. Selanjutnya, 25 larva diuji pada masing-masing konsentrasi ekstrak biji mahoni sebesar 8\%, 10\%, 20\%, dan 50\% dengan 3 kali pengulangan. Pengujian larva dilakukan menggunakan wadah plastik dengan total volume keseluruhan penambahan ekstrak dan air adalah $100 \mathrm{ml}$.

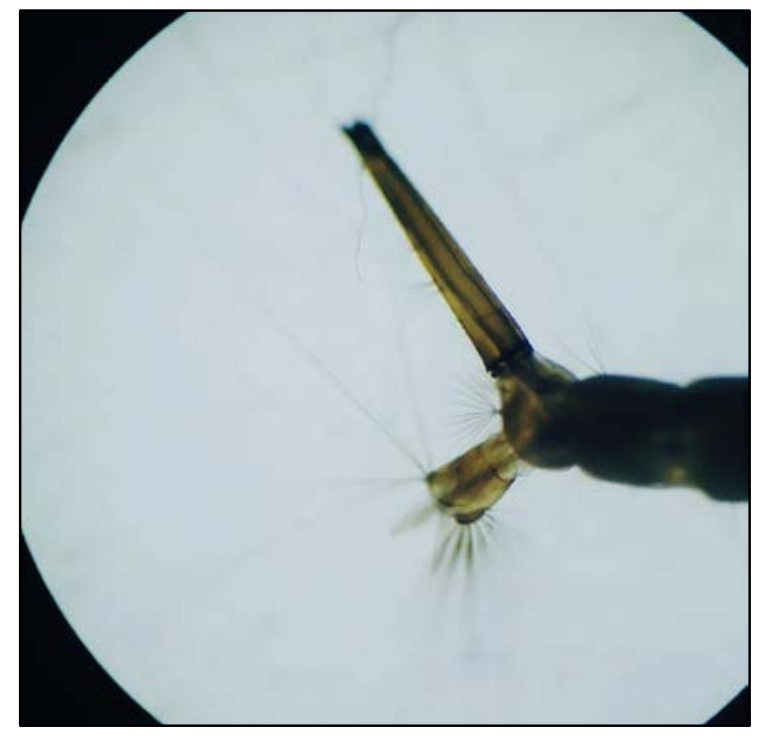

Gambar 1. Pengumpulan dan identifikasi larva Culex sp. berdasarkan sifon larva

\section{Pembuatan Ekstrak Biji Mahoni}

Pembuatan ekstrak merupakan hasil modifikasi dari metode maserasi. Biji mahoni dikupas dan dipisahkan bijinya. Biji mahoni dikeringkan menggunakan oven pada suhu $40^{\circ} \mathrm{C}$. Biji mahoni yang telah kering, kemudian diblender hingga dihasilkan serbuk biji mahoni. Serbuk biji mahoni seberat $100 \mathrm{~g}$ direndam menggunakan alkohol 96\% sebanyak $1 \mathrm{~L}$, diaduk lalu dibiarkan selama 48 jam. Alkohol dipilih karena efek toksik yang dimiliki lebih rendah dibandingkan dengan eter dan metanol. Setelah didiamkan, kemudian disaring menggunakan corong dan kertas saring. Penyimpanan digunakan untuk proses penguapan alkohol sehingga didapatkan 100\% ekstrak kental biji mahoni siap untuk di gunakan. Ekstrak biji mahoni diambil dengan menggunakan pipet volume dan kemudian di masukan ke dalam gelas ukur. Volume ekstrak biji mahoni diambil menggunakan rumus:

$$
V_{1} \cdot M_{1}=V_{2} \cdot M_{2}
$$

Keterangan:

$\mathrm{V}_{\mathrm{I}}=$ Volume awal

$\mathrm{M}_{1}=$ Konsentrasi zat mula-mula

$\mathrm{V}_{2}=$ Volume setelah pengenceran

$\mathrm{M}_{2}=$ Konsetrasi setelah pengenceran 


\section{Uji Efektifitas terhadap Larva Culex sp}

Larva instar III dipaparkan dengan ekstrak biji mahoni. Sebanyak 25 larva dipisahkan ke dalam wadah uji kemudian diuji menggunakan konsentrasi ekstrak biji mahoni 8\%, 10\%, 20\%, dan 50\% dengan tiga kali pengulangan. Pengamatan dilakukan pada waktu 15 menit, 60 menit, 120 menit, 240 menit, 420 menit, dan 720 menit. Mortalitas larva dihitung menggunakan rumus ${ }^{17}$ :

Keterangan:

$$
M=\frac{M_{1}}{M_{0}} \times 100 \%
$$

M : Mortalitas larva nyamuk

$\mathrm{M}_{0}$ : Total jumlah larva nyamuk yang diumpan $\mathrm{M}_{1}$ : Jumlah larva yang mati

\section{Analisis Data}

Penelitian ini dianalisis menggunakan software SPSS 15.00 dengan metode ANOVA

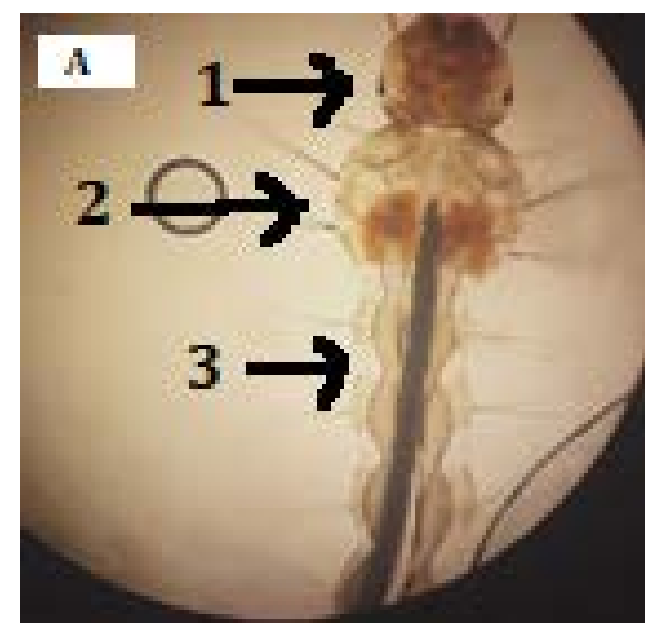

(Analysis of Variance) untuk menentukan pengaruh antara pemberian ekstrak biji mahoni terhadap kematian larva dan analisis probit untuk menentukan lethal time (LT50) dan lethal concentration $\left(\mathrm{LC}_{50}\right)$. Selanjutnya dilakukan uji korelasi untuk melihat derajat/keeratan hubungan antara kosentrasi dan mortalitas kemudian dilakukan uji regresi.

\section{HASIL}

Larva Culex sp yang telah diberi ekstrak biji mahoni diamati untuk melihat adanya kerusakan morfologi. Berdasarkan gambar 1 terlihat bahwa larva yang telah diberi ekstrak biji mahoni mengalami kerusakan di bagian caput, abdomen dan toraks. Caput mengalami kerusakan dan abdomen terlihat transparan, diduga mengalami penipisan lapisan kutikula. Dari 300 sampel yang digunakan hampir semua sampel mengalami kerusakan toraks dan abdomen seperti yang tertera pada Gambar 1.

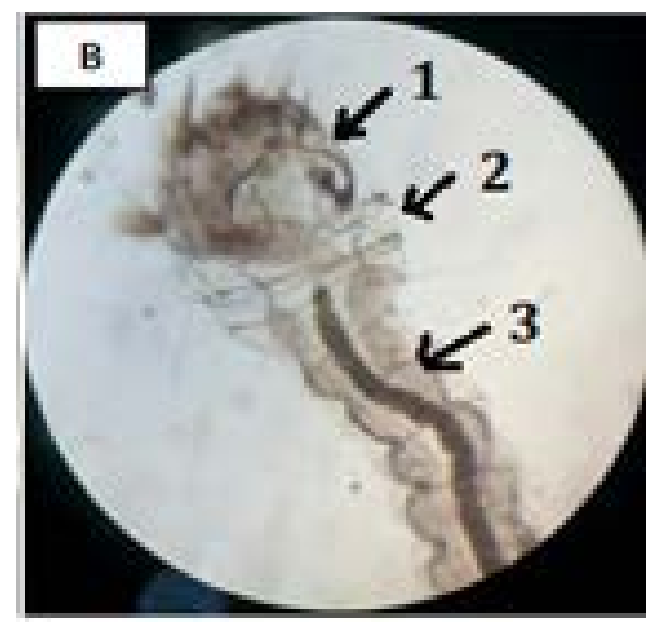

Gambar 1. Perubahan morfologi larva Culex sp. A) Sebelum pemberian ekstrak biji mahoni caput (1), torak (2), dan abdomen (3) terlihat jelas. B) Setelah pemberian ekstrak biji Mahoni terjadi kerusakan caput (1), torak (2) dan abdomen (3) yang lebih transparan.

Tabel 1. Jumlah Mortalitas Larva Culex sp.

\begin{tabular}{|c|c|c|c|c|c|c|}
\hline \multirow{3}{*}{ Konsentrasi } & \multirow{3}{*}{ Jumlah Larva Uji } & \multicolumn{3}{|c|}{ Jumlah Mortalitas } & \multirow{3}{*}{ Jumlah } & \multirow{3}{*}{ Mortalitas \% } \\
\hline & & \multicolumn{3}{|c|}{ Ulangan } & & \\
\hline & & 1 & 2 & 3 & & \\
\hline $8 \%$ & 25 & 10 & 12 & 10 & 9 & $36 \%$ \\
\hline $10 \%$ & 25 & 18 & 15 & 13 & 14 & $56 \%$ \\
\hline $20 \%$ & 25 & 20 & 19 & 20 & 19 & $76 \%$ \\
\hline $50 \%$ & 25 & 25 & 24 & 25 & 25 & $100 \%$ \\
\hline Kontrol Negatif & 25 & 0 & 0 & 0 & 0 & 0 \\
\hline
\end{tabular}


Berdasarkan Tabel 1, dapat dilihat bahwa pada konsentrasi 50\% ekstrak biji mahoni menunjukan persentase jumlah kematian larva yang paling besar yaitu 100\% dan konsentrasi 8\% menunjukan persentase jumlah kematian yang paling kecil yaitu 36\%. Kontrol negatif yang menggunakan aquades tidak terdapat kematian larva.

Tabel 2. Jumlah Mortalitas Larva Culex sp. Setelah Pemberian Ekstrak Biji Mahoni (Swietenia mahagoni) Berdasarkan Konsentrasi (LC)

\begin{tabular}{crcc}
\hline $\begin{array}{c}\text { Mortalitas } \\
\text { (\%) }\end{array}$ & \multicolumn{1}{c}{$\begin{array}{c}\text { LCx } \\
\mathbf{( \% )}\end{array}$} & $\begin{array}{c}\text { Batas } \\
\text { Bawah (\%) }\end{array}$ & $\begin{array}{c}\text { Batas } \\
\text { Atas (\%) }\end{array}$ \\
\hline 10 & -5.409 & -38.152 & 2.135 \\
20 & 060 & -23.041 & 5.703 \\
30 & 4.003 & -12.317 & 8.447 \\
40 & 7.373 & -3.472 & 11.111 \\
50 & 10.522 & 4.009 & 14.387 \\
\hline
\end{tabular}

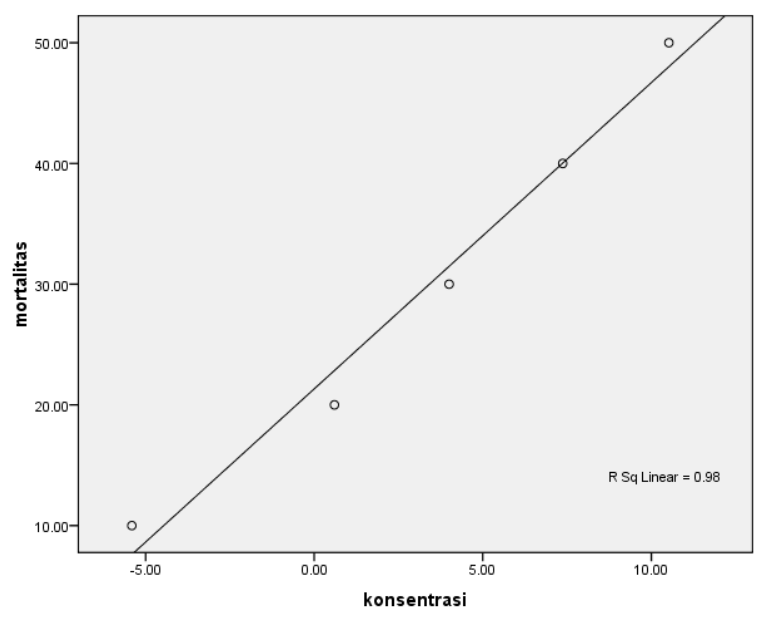

Gambar 2. Grafik persamaan garis regresi linier sederhana kematian larva terhadap konsentrasi ekstrak biji mahoni.

Dari Tabel 2, LC 50 Ekstrak biji mahoni terhadap kematian larva Culex sp. dihitung menggunakan analisis probit, sehingga didapatkan $\mathrm{LC}_{50}$ terletak pada konsentrasi $10 \%$.

Terdapat hubungan yang kuat $(\mathrm{R}=0.99)$ dan berpola positif antara konsentrasi ekstrak biji mahoni dengan kematian larva Culex, sehingga semakin tinggi konsentrasi ekstrak biji mahoni semakin tinggi jumlah kematian larva Culex sp.
Nilai koefisien determinansi 0.98 menerangkan 98\% variasi mortalitas atau persamaan garis cukup baik untuk menjelaskan variable mortalitas. Hasil uji statistik menunjukan ada hubungan antara mortalitas dengan konsentrasi ( $p$-value 0.001 ).

Berdasarkan mortalitas dari masing-masing konsentrasi dapat dihitung $\mathrm{LT}_{50}$. Lethal Time 50, yaitu waktu yang di butuhkan untuk membunuh $50 \%$ larva. nilai $\mathrm{LT}_{50}$ dari ekstrak biji mahoni adalah 204,23 menit (Tabel 3).

Analisis bivariat digunakan untuk menemukan perbedaan jumlah kematian larva Culex sp. antar kelompok uji. Berdasarkan uji ANOVA di dapatkan bahwa $F_{\text {hitung }}$ sebesar 51,560 (nilai $F_{\text {hitung }}>0,01$ ) yang berarti ada perbedaan variansi yang signifikan dari pemberian ekstrak biji mahoni terhadap kematian larva Culex sp.

Uji ANOVA dilanjutkan dengan uji Duncan untuk menilai perbedaan antarperlakuan. Berdasarkan uji Duncan didapatkan konsentrasi yang sangat berpengaruh terhadap kematian larva Culex sp., yaitu konsentrasi $50 \%$. Konsentrasi 8\% kurang memiliki pengaruh yang baik terhadap kematian larva.

\section{PEMBAHASAN}

Pengamatan morfologi larva dilakukan untuk mengetahui adanya kerusakan atau perubahan yang terjadi. Secara mikroskopis morfologi larva Culex sp. meliputi toraks, sifon, dan abdomen sebelum perlakuan terlihat normal. Larva sangat aktif bergerak naik-turun. Setelah pemberian ekstrak biji mahoni, pergerakan larva melambat. Larva Culex sp. yang mati mengalami kerusakan pada bagian toraks dan abdomen yang terlihat transparan. Hal ini diduga karena banyaknya senyawa toksin yang terkandung di dalam ekstrak biji mahoni, yaitu senyawa limonoid, alkaloid, flavonoid, dan saponin. Chaieb menyatakan bahwa kerusakan abdomen atau perut karena tumbuhan mahoni berfungsi sebagai antifeedant bagi larva yang berfungsi menghambat kemampuan makan larva sehingga kerja hormon pertumbuhan dan ekdison terganggu. Akibatnya torak dan abdomen larva terlihat transparan pada pengamatan mikroskopik. ${ }^{11}$

Tabel 3. Jumlah Kematian Larva Culex sp. Setelah Pemberian Ekstrak Biji Mahoni Berdasarkan Waktu (Lethal Time)

\begin{tabular}{ccccc}
\hline Konsentrasi (\%) & Mortalitas (\%) & LTx (menit) & Batas Bawah (menit) & Batas Atas (menit) \\
\hline 8 & 50 & 1110,11 & 667,25 & 148157,57 \\
10 & 50 & 646,32 & 426,10 & 3844,50 \\
20 & 50 & 361,64 & 211,17 & 543,10 \\
50 & 50 & 204,23 & 148.68 & 264,00 \\
\hline
\end{tabular}


Larva yang mati merupakan larva yang tenggelam ke dasar wadah dan tidak merespon rangsangan, terpisah dengan larva lain yang dapat bergerak dengan jelas. Larva ini tidak bergerak setelah disentuh dengan jarum atau lidi pada bagian sifon. Larva yang hampir mati adalah larva yang tidak dapat naik ke permukaan dan tidak menyelam ke dasar permukaan air meskipun digoyangkan atau digerakan. ${ }^{17}$

Pada konsentrasi $10 \%$, ekstrak biji mahoni dapat membunuh $50 \%$ populasi larva yang ada dalam waktu 1.110,11 menit. Sedangkan untuk LT $_{50}$ yang paling cepat adalah konsentrasi $50 \%$ yang efektif membunuh larva dalam waktu 204,23 menit. Hasil analisis LT 50 juga di lakukan oleh Khumaisah dan Kadarohman pada 2010, dengan $\mathrm{LT}_{50}$ yang efektif untuk membunuh larva Culex sp pada menit ke 1.351,6. Dari hasil tersebut dinyatakan jika ekstrak biji mahoni lebih efektif membunuh larva Culex sp. dengan waktu yang sangat cepat dibandingkan akar wangi. ${ }^{18}$ Penelitian yang dilakukan oleh Adhikari et. al menggunakan daun mahoni yang berbentuk jelly diperoleh hasil bahwa pada konsentrasi $50 \%$ pada stadium 3 dapat membunuh 90\% larva Culex quinquefasciatus dalam waktu 4.320 menit.19 Apabila dibandingkan dengan ekstrak daun mahoni, ekstrak biji mahoni kurang efektif dalam membunuh larva Culex. Selain itu, ekstrak daun mahoni juga bisa membunuh Culex vishnui ${ }^{13}$ dan juga Anopheles stephensi ${ }^{14}$ baik dalam bentuk jelly, coil, maupun serbuk nanopartikel. ${ }^{15}$

Konsentrasi ekstrak yang memberikan pengaruh yang signifikan adalah konsentrasi 50\%. Perbedaan konsentrasi ekstrak memiliki pengaruh yang signifikan terhadap kematian larva. Semakin tinggi konsentrasi ekstrak biji mahoni, semakin tinggi angka kematian larva Culex sp. Tingginya angka kematian diduga juga disebabkan karena tingkat kekentalan ekstrak biji mahoni yang dapat mengganggu pergerakan larva ke permukaan untuk mengambil oksigen. Hal ini sesuai dengan pernyataan dari penelitian sebelumnya yang dilakukan oleh Chaieb pada 2010, yang menyimpulkan bahwa antifeedant pada ekstrak biji mahoni dapat menghambat pertumbuhan larva sehingga hormon pertumbuhan dan ekdison terganggu yang menyebabkan torak dan abdomen larva menjadi lebih transparan. ${ }^{11}$ Selain itu, terjadi kerusakan pada bagian toraks dan abdomen setelah diamati secara mikroskopis. Peningkatan konsentrasi menyebabkan peningkatan kematian larva juga dibuktikan dalam penelitian yang telah dilakukan oleh Koneri dan Pontororing pada 2016, yang menyimpulkan bahwa semakin tinggi tingkat kosentrasi, semakin tinggi pula kandungan racun yang ada pada ekstrak biji mahoni. Akibatnya, semakin cepat proses paralisis larva tersebut karena ekstrak biji mahoni dapat menghambat kemampuan makan larva dan menekan aktivitas sistem saraf larva. ${ }^{20}$

Ekstrak biji mahoni juga efektif untuk mengendalikan larva selain Culex sp., diantaranya larva Plutella xylostella yang menyerang tanaman sawi ${ }^{21}$ dan kubis $^{22}$, larva nyamuk Aedes aegypti ${ }^{23,24}$, dan mengendalikan ulat grayak pada tanaman cabe rawit. ${ }^{25}$ Penelitian yang dilakukan oleh Yanti dan Hepiyansori pada 2018 juga menyatakan bahwa ekstrak biji mahoni yang dibuat dalam bentuk coil, bukan ekstrak mentah, juga efektif dalam membunuh nyamuk dewasa. ${ }^{26}$ Begitu banyak manfaat ekstrak biji mahoni dalam pengendalian yang tidak hanya membunuh larva Culex sp., tetapi juga dapat membunuh hama lain sehingga ekstrak biji mahoni bisa dipertimbangkan sebagai alternatif pengendalian vektor maupun hama.

\section{KESIMPULAN}

Pemberian ekstrak biji mahoni (Swietenia mahagoni) mengakibatkan kerusakan morfologi larva Culex sp., meliputi kerusakan di bagian abdomen dan torak hingga abdomen mengalami penipisan kutikula. Dari penelitian ini didapatkan $\mathrm{LC}_{50}$ pada konsentrasi ekstrak biji mahoni $10 \%$ dan $\mathrm{LT}_{50}$ pada konsentrasi ekstrak 50\%. Semakin tinggi konsentrasi semakin banyak mortalitas larva. Ekstrak biji mahoni memiliki dampak yang signifikan terhadap kematian larva Culex sp.

\section{KONTRIBUSI PENULIS}

Peran penulis pada artikel ini, yaitu Lisa Hidayati sebagai kontributor utama, sedangkan Seli Suprihatini sebagai kontributor anggota. Detail kontribusi penulis dapat dilihat pada rincian berikut:

$\begin{array}{lll}\text { Konsep } & : & \text { LH } \\ \text { Analisis Data } & : & \text { LH, SS } \\ \text { Investigasi } & : & \text { LH, SS } \\ \text { Pengawasan } & : & \text { LH } \\ \text { Validasi } & : & \text { LH, SS } \\ \text { Visualisasi } & : & \text { SS } \\ \begin{array}{l}\text { Menulis-Pembuatan } \\ \text { Draft }\end{array} & : & \text { LH, SS } \\ \begin{array}{l}\text { Menulis-Mengkaji } \\ \text { dan Mengedit }\end{array} & : & \text { LH, SS }\end{array}$




\section{DAFTAR RUJUKAN}

1. Astuti, E. P., Ipa, M., Riandi, M. U. \& Wahono, T. Mengenal filariasis: Penyakit tropis yang terabaikan di Jawa Barat. (Penerbit PT Kanisius, 2014).

2. W.H.O. Weekly epidemiological record. http://www.sidalc.net/cgi-

bin/wxis.exe/?IsisScript=KARDEX.xis\&meth od $=$ post $\&$ formato $=2 \&$ cantidad $=1 \&$ expresio $\mathrm{n}=\mathrm{mfn}=003687$ (2013).

3. Susanna, D. \& Uli J. Sembiring, T. Entomologi kesehatan: Arthropoda pengganggu kesehatan dan parasit yang dikandungnya. (UI-Press, 2011).

4. Kementerian Kesehatan RI. Pusat data dan informasi kementerian kesehatan RI: Menuju Indonesia bebas filariasis. (2018).

5. W.H.O. Temephos in drinking water: Use for vectrol control in drinking water sources and containers. (2009).

6. Putri, D. M., S, M. A. \& Supriatno. Efektivitas larvasida ekstrak etanol daun alpukat terhadap mortalitas larva Aedes aegypti dan Culex quinquefasciatus. J. EduBio Trop. 6, 172 (2018).

7. Pratiwi, A. Penerimaan masyarakat terhadap larvasida alami. KEMAS 8, 88-93 (2012).

8. Fadhil, M., Desnita, E. \& Elianora, D. Uji efektifitas ekstrak biji mahoni (Swietenia mahagoni (L.) Jacq) sebagai antipiretik pada tikus wistar (Rattus norvegicus). J. B-Dent 4, 141-149 (2017).

9. Rindawati, N., Daniel \& Saleh, C. Uji fitokimia, uji toksisitas, dan aktivitas antioksidan dari biki tumbuhan mahoni (Swietenia mahagoni (L) Jacq). J. At. 4, 78-81 (2019).

10. Abdelgaleil, S. A. ., Doe, M. \& Nakatani, M. Rings B,D-seco limonoid antifeedants from Swietenia mahogani. Phytochemistry 96, 312-317 (2013).

11. Chaieb, I. Saponins as insecticides: a Review. Tunis. J. Plant Prot. 5, 39-50 (2010).

12. Rasyad, A. A., Mahendra, P. \& Hamdani, Y. Uji Nefrotoksik dari ekstrak etanol biji mahoni (Swietenia mahagoni Jacq.) terhadap tikus putih jantan galur wistar. J. Penelit. Sains 15, 15216-79-15216-82 (2012).

13. Adhikari, U. \& Chandra, G. Laboratory evaluation of ethyl acetate and chloroform: methanol $(1: 1 \mathrm{v} / \mathrm{v})$ extract of Swietenia mahagoni leaf against Japanese Encephalitis vector Culex vishnui group. Asian Pasific J. Trop. Dis. 2, 451-455 (2012).

14. Adhikari, U. \& Chandra, G. Larvicidal, smoke toxicity, repellency and adult emergence inhibition effects of leaf extracts of Swietenia mahagoni Linnaeus against Anopheles stephensi Liston (Diptera: Culicidae). Asian Pasific J. Trop. Dis. 4, S279-S283 (2014).

15. Adhikari, U., Bhattacharya, K., Mitra, P. \& Chandra, G. Larvicidal efficacy of silver nanoparticles synthesized biologically using Swietenia mahagony (L.) Jacq. leaf extract against Anopheles stephensi, Culex quinquefasciatus and $\mathrm{Cx}$. vishnui group. Indian J. Exp. Biol. 56, 14-19 (2018).

16. Ramadhani, T., Yuliani, V., Hadi, U. K., Soviana, S. \& Irawati, Z. Tabel hidup nyamuk vektor filariasis limfatik Culex quinquefasciatus (Diptera: Culicidae) di Laboratorium. J. Kesehat. Lingkung. Indones. 18, 73-80 (2019).

17. W.H.O. Guidelines for laboratory and field testing of mosquito larvicides. World Health Organization http://whqlibdoc.who.int/hq /2005/WHO_CDS_WHOPES_GCDPP_2005.1 3.pdf?ua=1 (2005) doi:Ref: WHO/CDS/ WHOPES/GCDPP/2005.11.

18. Khumaisah, L. L., Kadarohman, A. \& Eko, R. Efektivitas biolarvasida ekstrak etanol limbah penyulingan minyak akar wangi (Vetiveria zizanoides) terhadap larva nyamuk Aedes aegypti, Culex sp., dan Anopheles sundaicus. J. Sains dan Teknol. Kim. 1, 59-65 (2010).

19. Adhikari, U., Singha, S. \& Chandra, G. In vitro repellent and larvicidal efficacy of Swietenia mahagony against the larval forms of Culex quinquefasciatus Say. Asian Pac. J. Trop. Biomed. 2, S260-S264 (2012).

20. Koneri, R. \& Pontororing, H. H. Uji ekstrak biji mahoni (Swietenia macrophylla) Terhadap larva Aedes aegypti vektor penyakit demam berdarah. J. MKMI 12, 216-223 (2016).

21. Heviyanti, M., Husni \& Rusdy, A. Efektifitas ekstrak biji mahoni (swietenia mahogani jacq.) terhadap mortalitas dan rata-rata waktu kematian larva Plutella xylostella pada tanaman sawi. Agrosamudra 3, 27-38 (2016).

22. Ariyanti, A. P. D., Subagia \& Sulistyo, A. Toksisitas ekstrak biji mahoni terhadap ulat Plutella xylostella pada daun kubis. AgroSains 22, 1-6 (2020).

23. Amirullah, Malik, N. \& Nurhiliya, E. Uji efikasi ekstrak daun sereh (Andropogon nardus) dan biji mahoni (Swietenia macrophylla) terhadap mortalitas larva Aedes aegypti. 5, 838-852 (2018).

24. Rizkika, T., Amelia, N., Sumarmi, S. \& Nuringtyas, T. R. Efektifitas ekstrak etanol 
daun mahoni (Swietenia mahagoni (L.) Jacq.) terhadap larva Aedes aegypti L. J. Florea 4, 23-30 (2017).

25. Septian, R. E. \& Ratnasari, E. Pengaruh Kombinasi ekstrak biji mahoni dan batang brotowali terhadap mortalitas dan aktivitas makan ulat grayak pada tanaman cabai rawit. Lentera Bio 2, 107-112 (2013).

26. Yanti, Y. N. \& Hepiyansori. Ekstrak biji mahoni (Swietenia mahogani (L.) Jacq) untuk pembuatan obat anti nyamuk elektrik. J. Katalisator 3, 7-11 (2018). 